\title{
Exploring the Characteristics of Prosperous SMEs in the Caribbean
}

\author{
Densil A. Williams \\ Mona School of Business \& Management, Kingston, Jamaica \\ densil.williams@uwimona.edu.jm \\ Boumediene Ramdani \\ University of Exeter Business School, Exeter, UK
}

Accepted for Publication in the Entrepreneurship and Regional Development 


\section{Exploring the Characteristics of Prosperous SMEs in the Caribbean}

Despite the extensive literature on small business growth and performance, relatively little is known on the features of firms that have been prosperous for a long period of time. Adopting Storey's determinants of growth framework, this study explores the characteristics of the entrepreneur, the firm, and the firm's strategy contributing to the prosperity of small firms in the Caribbean. Using multiple case studies from across the region, this study reveals that SME prosperity in the Caribbean seems to depend on combining certain characteristics namely, the entrepreneur's strategic leadership, networks, and intimate knowledge of products and business operations, and the firm's strategy of branding and market diversification. The findings show that unlike the results from previous studies in large and developed countries, it is a mix of these characteristics that determines SME prosperity. Research and policy implications of these findings are discussed.

Keywords: SMEs; prosperity; growth; performance; small and developing economies; Caribbean 


\section{Introduction}

Although a significant body of research has examined SME performance (e.g. Altman and Narayanan, 1997, Dobbs and Hamilton, 2007, Gibb and Davies, 1990, Wiklund et al., 2009), much of it is contradictory and provides a weak basis for entrepreneurs, academics, and policy makers to forecast performance. Besides, the general body of work on SME performance is heavily focused on the context of large and developed countries where socio-economic and institutional factors are different from those of smaller and less developed economies (Blair-Henry and Miller, 2008). As a result, replicating findings on prosperous SMEs, or research in general, from larger and developed country context is not only risky but dangerous (Campbell et al., 2012, Kiss et al, 2011, Lashley, 2003, Nicholson and Lashley, 2016, Obeng et al., 2014, Watson, 2007, Williams, 2015a). This study therefore, takes a context specific look at the characteristics of prosperous SMEs in the Caribbean, an area of the work where little is known on this subject.

It is interesting to explore the characteristics of prosperous SMEs in the Caribbean for several reasons. According to the IMF, the Caribbean economies face many challenges including low growth, high debt, and vulnerabilities from natural disasters (Acevedo et al., 2013). Besides, the Caribbean countries rank poorly in the Global Competitiveness Index (Schwab and Sala-i-Martin, 2015), and the business climate suffers from many weaknesses including but are not limited to: instability in the macro-economy (major impediment to doing business as it brings unintended cost to business operations), limited access to finance, contract enforcement, and security concerns (Wint, 2003, World Bank, 2016). In addition, Caribbean economies have less developed institutional arrangements such as: legal system to settle disputes in business, 
commerce and property rights issues; high levels of crime and violence which can be viewed as an additional tax to doing business; and small domestic markets which makes it difficult for firms to derive economies of scale and scope in production and distribution (Blair-Henry and Miller, 2008, Harris, 1997, Wint, 2003). Firms operating in such markets with these conditions will undoubtedly find it more difficult to prosper. Despite the less than benign business environment in these economies, some small firms still perform strongly while many others fail. To provide insights as to why this is the case, our study aims to explore the characteristics of prosperous firms in the context of low growth and unstable macro-economic environment of the Caribbean region.

Exploring the characteristics of these SMEs will provide an understanding of how small firms, with very limited resources, operating in such inhospitable environments are able to compete, survive, and prosper (Hall, 1995, Williams, 2015b). This study, grounded in the SME growth and performance literature, will not only add new insights from a novel context, but also provides theorist in the field with another context in which to draw conclusions from, and help to build a strong theory to explain SME growth and performance.

To shed light on the characteristics of small firms that have prospered in the Caribbean context, this paper will be organised as follows. The next section will provide the theoretical underpinning of SME prosperity. Following that, the research method used to collect data and analyse the findings will be highlighted. The subsequent sections will present the research findings and discussions. Finally, the paper will summarise the findings and highlight their implications for research as well as policymaking. 


\section{Theoretical Underpinning}

The SME performance literature is replete with theoretical lenses that are geared towards improving our understanding of why some firms perform better than others. These theoretical lenses include: the resource-based view which argues that firms possessing resources that are rare, valuable, non-imitable and unique will have a stronger competitive advantage over rivals (Amit and Schoemaker, 1993, Barney, 1991, Thornhill and Amit, 2003, Penrose, 1959, Wernefelt, 1984); efficiency theory which argues that firms learn to be efficient and thus reduce cost giving them competitive edge (Jovanovic, 1982); limited portfolio theory which posits that firms that perform well have a larger portfolio of products and markets and as such can gain economies of scale and reduced cost of production (Hall, 1995); and organizational ecology which postulates that, it is internal management decisions that result in firm success or failure rather than other factors external to the firm (Hannan 1997, Hannan and Freeman, 1988).

Despite these lenses, scholars have observed that the literature suffers from a weak theoretical base (Leitch et al., 2010) and limited empirical evidence (Blackburn et al., 2013). Researchers in this line of work are still facing the challenge of theorising small firm growth and performance due to its complexity (St-Jean et al., 2008). Most of the existing research tends to consider the extent of growth to analyse small firm performance even though there are several different ways as to how SMEs achieve growth (McKelvie and Wiklund, 2010). Moreover, explaining the process of small firm growth using stage models has not led to significant progress in the field since these models are not based on evidence and rely on normative assumptions (Gibb, 2000). Still, another criticism of this field is the total dedication to quantitative and variable- 
centred studies to explain SME performance (e.g. Barkham et al., 2002, Blackburn et al., 2013, Hart and Gudgin, 1999, Hart and Roper, 2004, Kirkwood, 2009, Littunen and Niittykangas, 2010, Openg et al., 2014). Moreover, most researchers focus on general (demographic) factors affecting growth (Wiklund et al, 2009), and tend to pick and choose from a list of attributes that have been empirically tested and validated to influence SME performance. Indeed, the criticisms of the quantitative works are not geared at dismissing the valuable contributions of such work, but to caution that causality as implied in the quantitative techniques can be difficult to establish due to non-linearity of relationships, and the problem with modelling determinants of SME growth (Storey, 2011).

Indeed, researchers argue that the complexity and multidimensional nature of SME performance makes it difficult for quantitative studies to capture characteristics that "all need to combine appropriately in order that the firms achieve rapid growth" (Storey, 1994, pp. 122). This is due to the heterogeneity of growth experience among SMEs making it hard to predict the influential factors over time (Blackburn et al., 2009). Qualitative studies (e.g. Barringer et al., 2005, Blackburn et al., 2009, St-Jean et al., 2008) enriched existing evidence by unravelling the characteristics of small firms achieving growth. This study aims to contribute to this growing body of work by attempting to explore and understand the characteristics of prosperous SMEs in the Caribbean region. This will complement and provide additional evidence to better understand the determinants of small business growth.

Although numerous determinants have been proffered for SME growth and performance, the challenge of which specific configurations of these characteristics will 
work in which context remains unexplored (Hansen and Hamilton, 2011). Empirical studies have shown that different configurations of characteristics lead to SME growth and prosperity (e.g Baum et al., 2001, Freel and Robson, 2004, Smallbone et al., 1995, Smallbone and Wyer, 2000, Wiklund et al., 2009). The diverse findings of these studies could be attributed to using various theoretical lenses as mentioned earlier. To bring together the mix of characteristics that are observed among prosperous small businesses, this study uses Storey’s (1994) determinants of growth framework.

Storey (1994) observed that, the performance of SMEs is not unidimensional, but it is linked to three components: the entrepreneur, the firm, and the firm's strategy. Indeed, this framework has been used and supported by many empirical studies to show that the prosperity of small firms is determined by a mix of attributes of the entrepreneur, the firm and firm's strategy characteristics. Table 1 summarises these studies. Despite the framework being established to study high growth firms, its application in other contexts will be fruitful. This framework has been used by scholars to show the characteristics of prosperous SMEs in several countries using both qualitative and qualitative methods. Because the empirical evidence on the determinants of small business growth and performance are inconclusive, further research is needed to show the mix of characteristics of prosperous SMEs in various contexts. 
Table 1. Empirical studies using Storey’s determinants of growth framework

\begin{tabular}{|c|c|c|c|c|c|}
\hline \multirow[b]{2}{*}{ Study } & \multicolumn{3}{|c|}{ Storey's Growth Framework } & \multirow[b]{2}{*}{ Method } & \multirow[b]{2}{*}{ Country } \\
\hline & $\begin{array}{c}\text { Characteristics of the } \\
\text { entrepreneur }\end{array}$ & $\begin{array}{c}\text { Characteristics of the } \\
\text { firm }\end{array}$ & $\begin{array}{c}\text { Characteristics of the firm's } \\
\text { strategy } \\
\end{array}$ & & \\
\hline $\begin{array}{l}\text { Openg et al. } \\
(2014)\end{array}$ & $\begin{array}{l}\text { Age; } \\
\text { Gender; } \\
\text { Formal qualifications; } \\
\text { Experience; }\end{array}$ & Size; & Export involvement; & $\begin{array}{l}\text { Ordinary } \\
\text { Least } \\
\text { Square } \\
\text { (OLS) }\end{array}$ & Ghana \\
\hline $\begin{array}{l}\text { Blackburn et al. } \\
\text { (2013) }\end{array}$ & $\begin{array}{l}\text { Age of owner-managers; } \\
\text { Owner-managers' business } \\
\text { style; }\end{array}$ & $\begin{array}{l}\text { Age of the business; } \\
\text { Size of business; } \\
\text { Industry; }\end{array}$ & $\begin{array}{l}\text { Business planning; } \\
\text { Collaborative activity by } \\
\text { owner-managers; }\end{array}$ & $\begin{array}{l}\text { Logit } \\
\text { Regression }\end{array}$ & UK \\
\hline $\begin{array}{l}\text { Hansen and } \\
\text { Hamilton } \\
(2011)\end{array}$ & $\begin{array}{l}\text { Opportunistic perceptions of } \\
\text { the external environment; } \\
\text { Use of extensive private } \\
\text { business networks; }\end{array}$ & $\begin{array}{l}\text { Culture of innovation } \\
\text { and flexibility; }\end{array}$ & $\begin{array}{l}\text { Owner-managers' controlled } \\
\text { ambitions; }\end{array}$ & $\begin{array}{l}\text { Case } \\
\text { Studies }\end{array}$ & $\begin{array}{l}\text { Christchurch, } \\
\text { New Zealand }\end{array}$ \\
\hline $\begin{array}{l}\text { Blackburn et al. } \\
\text { (2009) }\end{array}$ & $\begin{array}{l}\text { Education; } \\
\text { Motivation; }\end{array}$ & $\begin{array}{l}\text { Size; } \\
\text { Sector; }\end{array}$ & $\begin{array}{l}\text { Differentiation; } \\
\text { Innovation; } \\
\text { R\&D; } \\
\text { Marketing; } \\
\text { Export-orientation; }\end{array}$ & $\begin{array}{l}\text { Case } \\
\text { Studies }\end{array}$ & UK and USA \\
\hline $\begin{array}{l}\text { St-Jean et al. } \\
(2008)\end{array}$ & $\begin{array}{l}\text { Access to resources; } \\
\text { Motivation for growth; }\end{array}$ & Proximity to customers; & Adjustment capacity; & $\begin{array}{l}\text { Case } \\
\text { Studies }\end{array}$ & $\begin{array}{l}\text { Québec, } \\
\text { Canada }\end{array}$ \\
\hline $\begin{array}{l}\text { Barringer et al., } \\
(2005)\end{array}$ & $\begin{array}{l}\text { Relevant industry } \\
\text { experience; } \\
\text { College education; } \\
\text { Entrepreneurial story; }\end{array}$ & $\begin{array}{l}\text { Mission statement; } \\
\text { Commitment to growth; } \\
\text { Participation in } \\
\text { interorganisational } \\
\text { relationships; }\end{array}$ & $\begin{array}{l}\text { Create unique value; } \\
\text { Customer knowledge; } \\
\text { Training; } \\
\text { Financial incentives; } \\
\text { Stock options; }\end{array}$ & $\begin{array}{l}\text { Content } \\
\text { Analysis }\end{array}$ & USA \\
\hline $\begin{array}{l}\text { Hart and Roper } \\
(2004)\end{array}$ & $\begin{array}{l}\text { Founder of the firm; } \\
\text { Ownership; } \\
\text { Management style; } \\
\text { Prior experience; }\end{array}$ & Legal status; & $\begin{array}{l}\text { Export and domestic sales; } \\
\text { Innovation and quality } \\
\text { certification; } \\
\text { Strategic priorities; } \\
\text { Degree of formalisation of } \\
\text { business plan; }\end{array}$ & OLS & UK \\
\hline $\begin{array}{l}\text { Barkham et al. } \\
\text { (2002) }\end{array}$ & $\begin{array}{l}\text { Age; } \\
\text { Shared ownership; } \\
\text { Multi-ownership; } \\
\text { Member of a professional } \\
\text { organisation }\end{array}$ & Size; & $\begin{array}{l}\text { Increase profits; } \\
\text { Increase profit margins; } \\
\text { Focus on marketing; } \\
\text { Improve the production } \\
\text { process; }\end{array}$ & OLS & UK \\
\hline $\begin{array}{l}\text { Davidsson et al. } \\
(2002)\end{array}$ & & $\begin{array}{l}\text { Age of firm; } \\
\text { Business size; } \\
\text { Ownership; } \\
\text { Industrial sector; } \\
\text { Legal form; }\end{array}$ & Change in governance; & OLS & Sweden \\
\hline
\end{tabular}

With regard to the characteristics of the entrepreneur, the general literature suggests that owner-mangers are the most critical resource and their commitment to growth is vital to SME prosperity (Blackburn et al., 2013, Hansen and Hamilton, 2011, Mazzarol et al., 2009, Smallbone et al., 1995). The entrepreneurs' education and prior work experience (Delmar and Wiklund, 2008, Richbell et al., 2006, Williams, 2015b) as well as their capabilities (Barbero et al., 2011) have been linked to SME performance. Entrepreneurial style has also been found to be positively associated with higher growth (Sadler-Smith et al., 2003). Blackburn et al. (2013) found that owner-managers 
considering themselves to be "innovative and creating change" (pp. 22) are more likely to achieve higher growth rates.

As it relates to the characteristics of the firm element in the framework, prior studies have shown that as firms grow in size, they learn more about efficiency and how to stay in business (e.g. Hall, 1995, Jovanovic, 1982). However, more recent studies have shown that newer, smaller firms are more likely to survive with higher growth rates (e.g. Blackburn et al., 2013, Davidsson et al., 2006, Hamilton, 2012). These firms tend to be more flexible and quicker in responding to new opportunities compared to their larger counterparts (Escriba-Esteve et al., 2008, Steffens et al., 2009).

In addition to characteristics of the entrepreneur and the firm, the question this leaves unanswered is: what managerial actions could small firms implement to achieve growth? Using the resource-based view of the firm, it was established that firms acquiring resources that are difficult to imitate by rivals are more likely to achieve higher performance (Davidsson et al., 2006, Rangone, 1999). Contradictory evidence exists with regard to the role of planning in strategy formulation. While earlier studies have shown that business planning do not influence SME performance (e.g. Fletcher and Harris, 2002, Lyles et al., 1993), more recent studies confirm the positive association between business planning and SME growth (e.g. Blackburn et al., 2013, Richbell et al., 2006). Although very few firms actively engage with the formal planning, those that had growth strategies tend to also formalise their business planning (Richbell et al., 2006). Also, studies have found that fast-growing firms are more likely to have business plans (Mazzarol et al., 2009, Smallbone and Wyer, 2000). 
From this review of the literature, it appears that context plays a critical role in determining how the interplay of the entrepreneur, firm characteristics and firm strategy enables small firms’ prosperity. This study will contribute in this regard by replicating the framework in the context of the Caribbean, an under-studied geographical region in relation to SME growth and prosperity. Thus, this study explores the characteristics of prosperous small businesses in the Caribbean.

\section{Research Method}

Case study method is used to shed light on the characteristics of prosperous SMEs in the Caribbean. This method was chosen because it provides greater interrogation of the issues, especially given the novelty of the context in which the research is carried out (Eisenhart and Graebner, 2007, Yin, 2003). Compared to quantitative studies that look at causality (Wiklund et al, 2009), case study method allows for delving deeply into the mix of characteristics of prosperous small businesses in the Caribbean. Indeed, case studies, especially multiple cases, provide a rich real-world context in which the phenomenon under investigation occurs. Our study is derived from multiple cases across the Caribbean in order to explore SME prosperity.

This study followed a structured process to develop the cases under investigation. To ensure the highest standards of academic rigour, the cases were developed following the recommendations for case study design proposed by Eisenhart (1989) and Yin (2003). Since the objective of this research is not about testing existing theories on SME growth, it was not necessary to obtain a representative sample of firms for this study (Eisenhart and Graebner, 2007). As such, this study sought to select firms that help achieve the aim of the research, which is to identify the features that are common among prosperous SMEs in the context of the Caribbean. Only firms that were 
suitable for the purpose of this study were selected. The criteria used for selecting these cases are detailed in the next section.

\section{Selection Criteria}

In order to uncover the characteristics of small businesses that achieved growth and prosperity in the context of small developing economies, the companies selected as cases for our study had to meet the following criteria:

(1) Workforce of no more than 250 permanent employees;

(2) Indigenously owned;

(3) Existed for more than 10 years;

(4) Export to more than one market;

(5) Sells goods outside of the Caribbean region;

(6) Manufacture goods given that this sector has high level of openness and fierce competition from both locally produced and imported goods in the region.

The criteria above were applied to ensure that: the firms in the study do have some longevity in the marketplace; do not have any special support from large and resource rich multinational parent companies; and have the necessary competencies to operate overseas and win market-share on their own merit. These criteria are also crucial to ensure the long-term prosperity of these firms as the manufacturing sector of the region will become more competitive through either importing foreign products sold locally, or compete in export markets for these products.

The chambers of commerce and small business umbrella organisations across the five Caribbean countries were contacted to get a list of possible firms that meet the criteria to participate in the study. Of the five countries, firms from Jamaica, Belize and 
St. Kitts were eventually selected to participate in this study. Further details of these

firms are outlined in Table 2. The principals from these firms were willing and able to spend the time required to participate fully in the study. Subsequently, six firms were selected for the study.

Table 2. Demographic characteristics of SMEs selected for this study

\begin{tabular}{|c|c|c|c|c|c|c|c|c|c|}
\hline & No. of Staff & $\begin{array}{l}\text { No. of } \\
\text { Years in } \\
\text { Operation }\end{array}$ & $\begin{array}{l}\text { Governance } \\
\text { Structure }\end{array}$ & $\begin{array}{l}\text { Age } \\
\text { Group of } \\
\text { Owner/ } \\
\text { Manager }\end{array}$ & $\begin{array}{l}\text { Education Level } \\
\text { of Owner(s) }\end{array}$ & Family & $\begin{array}{l}\text { Export } \\
\text { Markets }\end{array}$ & $\begin{array}{l}\text { Previous } \\
\text { Export } \\
\text { Experience of } \\
\text { Owner }\end{array}$ & Sub-sector \\
\hline A & $\begin{array}{l}5 \text { permanent } \\
20 \text { temporary }\end{array}$ & 17 years & $\begin{array}{l}\text { Partnership } \\
\text { (3 Principal } \\
\text { Owners) }\end{array}$ & $55-60$ & $\begin{array}{l}\text { One owner has } \\
\text { BSc in French; } \\
\text { Another High } \\
\text { School Diploma; } \\
\text { Another MSc in } \\
\text { History }\end{array}$ & No & $\begin{array}{l}\text { USA, } \\
\text { Caribbean, } \\
\text { Canada }\end{array}$ & Yes & $\begin{array}{l}\text { Sauces and } \\
\text { Spices }\end{array}$ \\
\hline B & $\begin{array}{l}2 \text { permanent } \\
25 \text { temporary }\end{array}$ & 18 year & $\begin{array}{l}\text { Partnership } \\
\text { (2 Principal } \\
\text { Owners) }\end{array}$ & $50-55$ & $\begin{array}{l}\text { One owner with } \\
\text { PhD in } \\
\text { Chemistry; } \\
\text { Another with } \\
\text { MBA in Finance }\end{array}$ & No & $\begin{array}{l}\text { USA } \\
\text { (Mainly East } \\
\text { Coast) }\end{array}$ & Yes & $\begin{array}{l}\text { Fragrance } \\
\text { (Liquid } \\
\text { detergent) }\end{array}$ \\
\hline C & 22 permanent & 17 years & $\begin{array}{l}\text { Limited } \\
\text { Liability }\end{array}$ & $50-55$ & $\begin{array}{l}\text { High School } \\
\text { Diploma; }\end{array}$ & Yes & $\begin{array}{l}\text { Caribbean, } \\
\text { Canada }\end{array}$ & No & $\begin{array}{l}\text { Wood } \\
\text { Manufacturing }\end{array}$ \\
\hline $\mathbf{E}$ & 22 permanent & 37 years & $\begin{array}{l}\text { Limited } \\
\text { Liability }\end{array}$ & $55-65$ & $\begin{array}{l}\text { MSc in } \\
\text { Complementary } \\
\text { and Alternative } \\
\text { Medicine; }\end{array}$ & No & $\begin{array}{l}\text { USA, } \\
\text { Canada, UK, } \\
\text { Caribbean }\end{array}$ & Yes & $\begin{array}{l}\text { Beverages } \\
\text { (Teas) }\end{array}$ \\
\hline $\mathbf{F}$ & 12 permanent & 16 years & $\begin{array}{l}\text { Limited } \\
\text { Liability }\end{array}$ & $55-65$ & $\begin{array}{l}\text { MSc in History, } \\
\text { and Diploma I } \\
\text { Business; }\end{array}$ & Yes & $\begin{array}{l}\text { Canada, } \\
\text { USA, UK, } \\
\text { Caribbean }\end{array}$ & Yes & $\begin{array}{l}\text { Flavours and } \\
\text { Fragrances }\end{array}$ \\
\hline
\end{tabular}

\section{Data Collection and Analyses}

This section of the paper chronicles the steps that were taken from selecting the case studies to analysing the rich qualitative data derived from the in-depth interviews with owners-managers and other employees of SMEs across the Caribbean. The steps are non-mutually exclusive: documentary review to collect secondary data on the companies, primary data collection through in-depth interviews, and data analyses using qualitative data analysis software. 


\section{Documentary Review}

This stage of the research is where the researchers were engaged in reviewing the academic literature on SME growth and performance and in parallel, conducting a review of documents for each firm participating in this study. The aim of doing this documentary review was to provide historical background on these companies, information on the manufacturing sector in which they operate, and other details that might be relevant to the cases. In this way, the time spent on interviewing would be reduced as information that is readily available will not be required from the interviewees (Yin, 2003). One of the limitations, however, is that most small firms in the Caribbean do not have documentary details about their operations, as such information was very sparse in this regard. Indeed, some companies did not have as much as a functional website. Details such as historical information about the company had to be gleamed from the interviews. In some cases, historical background was taken from archival sources and print media such as the Jamaica Gleaner.

\section{Primary Data Collection}

Detail collection of information from an open-ended instrument was carried out in this phase. Comprehensive, open-ended interviews with owners (entrepreneurs), managers, employees, and other principals of the firms were conducted. In all cases, the interviews were tape-recorded and photographs were taken as evidence for the firm’s operations. Most interviews lasted for minimum of 90 minutes, and in some cases, interviews exceeded 120 minutes. This is very much in line with the recommendations put forward by many scholars who have been using narrative case studies as a research method for understanding individuals' lived experiences (Elliott, 2005). Interviewees were asked to discuss the lines of business they operate, the governance structure of their firms, and their business strategy among other issues. Overall, there were 4 broad open-ended 
questions with each question consisting of 5 sub-sections. This instrument was derived from previous literature on SME growth and performance (e.g. Hall, 1995, Lashley, 2003, Thornhill and Amit, 2003).

In all cases, the entrepreneurs (owner-managers) were interviewed first, and then key employees were interviewed subsequently. In some cases, close to the end of the interviewing process, the entire staff complement also joined the interviews along with their managers to give their impression of the company and its performance over time. In addition to the interviews, secondary data from company documents were also perused by the interviewers to gain further details during the interviews. The interviewers also observed the operations in the manufacturing plants while interviews were taking place. This provides a number of different avenues from which to verify statements and comments made during the interview with owners/managers. This multiple observation method is encouraged for case study research as it helps with verification (Einsenhart, 1989).

\section{Data Analyses}

The rich qualitative data gathered for this research was analysed at different levels. At a high level, the data gathering and analysis followed closely the narrative methodological framework (Elliot, 2005). Narrative refers to the extended prose, which outlines the discourse with the interviewee in a sequential order and meaningful way. To shed light on the characteristics of prosperous small businesses in the Caribbean, it was useful to have an insight into the lived experiences of the owners and how their experiences helped shape their business performance overtime. This sort of discovery process falls squarely within the conceptual nature of narrative analysis (Elliot, 2005). The research reported in this study will reflect what Carr (1997) referred to as 'first 
order narratives', which is defined as stories that individuals tell about themselves and their own experiences. It is from these stories that lessons will be drawn on what characteristics are most common among prosperous SMEs in the Caribbean.

The recorded interviews were transcribed into large volumes of data and then checked for accuracy; especially with dates and figures by sending back the draft cases to the business owners. The data were also coded based on findings from prior literature in order to identify thematic groups under which certain responses may fall. This led to a number of thematic areas which were linked to various findings in the extant literature. The direct narrative evidence from the cases was also used to match the coded themes to see how well they fit with the construct under investigation. To ensure accuracy and representation of the data gathered, the researchers developed the narrative for the cases and sent them to owners of the firms to ensure that the details are reflected accurately as discussed with the interviewees. All of the six firms were sent reports on the interview to the owner/managers, who responded and made minor corrections to the manuscripts, where necessary.

\section{Findings and Discussion}

The rich data collected from multiple cases were organised into themes with supporting evidence for each theme (Eisenhart and Graebner, 2007). Then, these themes were juxtaposed with the Storey's (1994) determinants of growth framework to see how best the extant findings reconcile or diverge from previous research.

The main objective of this study is to identify the characteristics of prosperous SMEs in a context where the business environment is inhospitable and markets are small and under-developed. These insights will not only provide further empirical evidence from a novel context, but also offer an understanding of the applicability of 
Storey’s (1994) framework to a broader under-studied context, the Caribbean. The analyses of the data reveal a number of important findings relating to SME prosperity in the Caribbean. Critically, this study shows that prosperous SMEs in the Caribbean have certain key characteristics which can be linked to the underlying conceptual framework for this study. These include both the entrepreneur and the firm's strategy elements of the framework. For the former, the entrepreneur's features include strategic leadership, network, and intimate knowledge of products and business operations. For the latter, the firm strategy features comprises branding and market diversification. Compared to previous works in larger and developed countries which argue that selected elements of Storey’s framework can explain SME prosperity and not necessarily a combination of these elements (Blackburn et al., 2013), this study found that the combination of the entrepreneur and firm strategy characteristics is what matters for SME prosperity in the context of the Caribbean region.

\section{Characteristics of the entrepreneur}

From the analysis of the data, several characteristics of the entrepreneur were found to be associated with prosperous SMEs in the Caribbean. These include: strategic leadership, network, and intimate knowledge of products and business operations.

Despite all the other attributes that drive SME performance, the one which the small firms in the Caribbean have identified as the most crucial is forward thinking and strong strategic direction from the owner of the firm. Put differently, strategic leadership is most important for SME prosperity. Indeed, SME owners are viewed as the heart and soul of their business. As such, almost all final decisions rest with the owners. Therefore, even when there may be consultations and advice sought from 
others, the final decision on the execution for projects is left with the owner/manager, unlike large and multinational firms where decisions are generally made by teams and approved by a Board of Directors. Most of the small firms in the Caribbean do not have formal governance structures and most of the power and responsibility tend to reside with the owners of these firms. It is not surprising, therefore, that forward thinking and strategic leadership from these individuals is crucial to the prosperity of these firms. For, without the leader embodying these characteristics, it will be difficult for them to envision changes in the environment that could negatively impact their firms, and may not be able to spot opportunities when they arise in very subtle ways. The evidence from the cases show that prosperous firms are those that have owner/managers who have forward thinking and strategic leadership traits in spotting opportunities in the global marketplace, analysing signals that are in their external environments that could potentially threaten their business, and designing workable plans to deal with business problems as they arise.

An anecdote from one of the owners portrays the role that forward thinking and strategic leadership play in SME growth:

“...put it this way...where we are now, we can't continue along the lines we are going. That is why we are trying to bring in an equity partner. We have to find the management skills, we have to get a production manager, preferably somebody with a degree...we want to eventually get someone who can grow into a general manager.....that is why we are putting a plan together. But we've reached the stage where we realise that...we are not going to be able to grow at the rate we want to achieve and want to grow at, or should be able to grow at, unless we strengthen the management in all aspects...financial management, accounting management and staff 
management, production management, and planning in terms of production and planning in terms of export marketing and growing of our production and exports...”

In addition to strategic leadership, for small businesses to prosper in a highly competitive and inhospitable environment, networking matters. The business and social networks of the owner/manager plays a significant role in garnering resources that the firm would not have otherwise possessed (Huggins 2000, Kristiansen, 2004). Further, diaspora markets also serve as a huge talent pool of resources both financial and human capital (Minto-Coy, forthcoming). These resources were reported to be crucial in providing the firm with a competitive advantage over those firms that are not part of the network. The owners of these firms have spoken extensively about their association with business networks such as business clubs serving as brainstorming sessions for market research, which helps them avoid carrying out extensive research at high cost they could not otherwise afford. The following quotation from one of the business owners whose firm had a name that was not attractive in the market and on changing the name, it saw significant appeal leading to increase in sales:

“... he became a charter member through the Rotary Club in San Ignacio, and once a year they have a spaghetti dinner that they do in the market; sort of like promoting Rotary with people. And they were doing the prep work the day before, you know, having a few beers, they were cutting up vegetables for cooking, stuff like that. And the gentleman said to my husband, 'what's with this name Food Limited? It is so boring.' And so my husband looked and said, 'well, I know but what do you do you think?' He said, - 'a real Belizean name-, it sounds like a Hot Mama's,' and that's how we got the name." 
Similarly, another owner spoke of the role of government network as important to the prosperity of his business as they open doors for business deals:

“... the Government.... I don't have a problem specifically, they support me a lot.... one of the thing we have done, once we make profits we support the Government for example, like the Police we donated stuff, anything that we can do for schools and hospitals, we always supportive of them...”

Besides social networks, building relationships with larger businesses was also seen to be critical for SME prosperity. The following anecdote from one of the cases is highly insightful regarding the role of networking between small and large multinational Caribbean firms working together to ensure prosperity:

“...a very good friend of mine when I was in the restaurant business, she was in charge of Grace Foods Services Division..... I said to her, ‘why can’t you sell my seasonings to the hotels?' and she said, 'let me put in a bid, because they will open up that new market'....the rest is history...we got the GraceKennedy deal and that started that business there..."

Another of example of business to business networking is found in the tea manufacturing operations:

“...And so locally, we have that competition with imported products; as I pointed out we do make some of the teas for Caribbean Dreams...... We have a friendly adversarial business relationship as two small Jamaican companies, we being the tiny one, and they the bigger one. We share our expertise and knowledge to some extent, and.... put it this way, we are friendly competitors if that is possible. And then we look more at the global markets in terms of exporting and earning foreign exchange. So, 
globally we go to the world market with what we like to think are unique Jamaican products; like our Jamaican peppermint...”

In addition, the entrepreneur intimate knowledge of their products and operations has been found to be a key characteristic of prosperous small businesses in the Caribbean . In the cases reported in this study, a common theme that emerged from the owners is that; in order for them to be successful, they need to have a comprehensive understanding of the line of business in which they operate. Most of the owners of the firms have started their businesses based on their own previous work knowledge and expertise, and/or have developed an idea based on their own academic pursuits. One entrepreneur sums up the importance of knowing his products and operations in order to ensure prosperity as follows:

"...The good thing with me, when I first started out, is that I as the owner/manager, I can do everything in this shop .... I think with anything that you are going to be successful with--, one has to understand how any product works and I think that's one of the key things, even in school, I remember going school and not understanding a lot of stuff and it is after I finished school... I actually started to understand what I was being taught. . Also, anything that you are going to do, you got to love it ....because I love what I do... I enjoy what I do, and that's real key to any business...”

\section{The firm's strategy}

Our findings indicate that the firm's strategy of prosperous SMEs in the Caribbean includes branding and market diversification. An important element in ensuring strong performance for Caribbean SMEs is the investment in building the brand for the 
company. The findings from the cases show that prospering SMEs spent significant amount of time in building their brands to compete in the marketplace. One of the entrepreneurs summed up the critical role of brand building to ensure strong firm performance by saying:

“...But you also wear the brand. We learnt this, everywhere you go, brand yourself. Whether it starts conversation on airplanes, in supermarkets, in banks, everywhere you go, it starts the conversation. You don't have big marketing funds when you start off, so you have to believe in the brand, you have to wear the brand, and show how enthusiastic you are. It will rub off. If you don't do that and you sit there in your office here and expect it to sell... you expect the caterer, you expect the distributor to take your brand new products with no image in the market it has gone into and expect to sell off the shelf? Unless it is half the price, the other ones up there won't sell. So you've got it the hard way...”

The lesson from the above anecdote is that small firms will need to invest human and financial resources to make their brands known in their domestic market, and use that branding to leverage international markets. Building the company's brand should not be seen as an expense for the company, but as a strategic investment that will eventually lead to long-term benefits and eventually their prosperity.

In addition to branding, market diversification has been found to be the one characteristic that prosperous small firms in the Caribbean tend to execute. The firms reported in this study did not depend on a single market in which to sell their outputs. Instead, they sold into various marketplaces both regionally and internationally. Clearly, what these small firms were trying to do in order to prosper is to overcome the limited portfolio stigma by diversifying their markets, and as a result these firms tend to depend 
less on any single location from which to derive their revenues. Indeed, while most of the companies interviewed did not report high levels of export sales, their aim was to have a foot-hold in international markets which were gained mostly through the owners' personal contacts. The sales from these international markets have helped these smaller companies to overcome cash flow challenges, which they continuously face because most customers in the domestic marketplace take a long time to pay. An observation that is important to note here is that all of the companies in the sample have had sales in international markets, whether through direct exporting or through unsolicited orders motivated mainly from their contacts abroad. The critical role of market diversification in ensuring business prosperity is summed up by an anecdote from one of the owners stating:

“...The other thing we've done over the period is not simply targeting only the Diaspora in the major con-urban areas of the US or Toronto or the UK; because that is a shrinking market to some extent. It's a very price driven market, it's overly competitive. There are brands from everybody in there. But the vast continent of North America is looking for taste, new flavours, new seasonings..... So you need still to service the Diaspora market because you need to fill your containers up to make sure you have sufficient volumes to make it worthwhile. But the biggest market untapped out there is the non-Caribbean, non-Diaspora market in many ways, like in food service, in restaurants.... we can never begin to fill the whole of that market as a country but we have a good chance of getting in, given the reputation of jerk and Jamaica......And it is those opportunities which represent by far the largest opportunities...”

Our findings suggest that SME prosperity in the Caribbean depends on combining certain characteristics of the entrepreneur and the firm's strategy. Previous 
studies, however, found that small business growth is heavily dependent on firm characteristics (e.g. Blackburn et al., 2013, Davidsson et al., 2002). Blackburn et al. (2013) found that firm characteristics such as size and age of the enterprise are more important than that of the characteristics of the entrepreneur and firm's strategy in the UK context. Similarly, Davidsson et al. (2002) found that the firm component (demographic characteristics of the firm) to be associated with Swedish SME growth. These findings reinforce the importance of context-specific studies since the mix of characteristics in the Caribbean context seems to differ from those in developed economies.

The results in this study also find resonance with previous work on SME performance. In their study to distinguish growers from non-growers, Hansen and Hamilton (2011) found that growers contrasted with non-growers among small firms in their growth ambition and strategic thinking. Also, the entrepreneur's network has been found to be associated with prosperous Caribbean SMEs. Firms with high-quality social networks (i.e. high number and variety of relations) are in a better position to grow their business through raising resources such as ideas, information, capital and trust (Kristiansen, 2004). Hansen and Hamilton (2011) found the use of extensive private business networks to be much more pronounced among the growers. This is in line with a recent meta-analysis of social network- performance link, which shows the "distinct networking strategies are needed at different points in time and in different industries and countries” (Stam et al., 2014, pp.19). Another important characteristic of the entrepreneur is their knowledge of products and business operations. Indeed, industry experience of the entrepreneur has been found to determine small business growth (Barringer et al., 2005), and the lack of managerial knowledge may weaken small firm's 
ability to grow (Goffee and Scase, 1995). Furthermore, Caribbean SME prosperity has been found to depend on brand development. Similar to the results in this study, Reijonen et al. (2012) found that growing SMEs to be more brand-oriented than stable or declining SMEs. Also, our study found that SME prosperity depends on market diversification, a characteristic that is linked to the firm's strategy component of the determinants of growth framework. Importantly, other studies have also found that market development strategy is indeed a key characteristic of SME growth (e.g. Smallbone et al., 1995).

\section{Conclusions and implications}

The aim of this study is to contribute to our understanding of the characteristics associated with prosperous small firms in the Caribbean. Drawing from multiple case studies and using Storey's determinants of growth framework as the guiding conceptual lense, the characteristics of the entrepreneur, the firm, and the firm's strategy were explored. Our findings suggest that Caribbean SMEs prosper when the entrepreneurs have strategic leadership capabilities, strong social and business networks, and intimate knowledge of their products and business operations. Moreover, the findings show that branding and market diversification are vital characteristics of prosperous small firms' strategy in the Caribbean. The interpretation of these findings suggest that; despite the inhospitable environment in which these firms operate, Caribbean SMEs have been able to prosper mainly due to the adroit leadership of their owners, whose strategic insights have allowed them to cultivate the necessary resources in their firms in order to overcome the turbulences of their external environments and ensure growth and prosperity of their businesses. 
Although this study has contributed to the current debate on SME growth and performance, it has some limitations that could open new pathways for future research. Indeed, due to the traditional limitations with case study method, our findings cannot be generalized beyond the study context. However, our findings can be used as the bedrock for further empirical work. Cross-sectional case studies could be carried out to validate our findings. Also, a fixed panel dataset could be created to track Caribbean SMEs overtime and examine the characteristics of high-performing SMEs. This could give further insights into the factors associated with these firms’ prosperity. Further, as this study focused only on the manufacturing sector, future research could investigate SME growth in other sectors such as services. It will be worth investigating whether the same characteristics (or different configurations) determine SME growth and prosperity in other industries. For example, the issue of the firm's brand can be achieved through building tangible products in the manufacturing sector as individuals can relate directly to these items. However, it might not be the same for the services sector where it is harder to make the business case for intangibles.

In contrast to previous research arguing that SME growth is heavily dependent on firm characteristics (e.g. Blackburn et al., 2013, Davidsson et al., 2002), this study shows that SME prosperity, a proxy for growth, is dependent on the characteristics of the entrepreneur and the firm's strategy. Future research need to validate these findings by exploring which characteristics (the entrepreneur, the firm, the firm's strategy) do firms most depend on. To highlight context-specific characteristics, future work could conduct meta-analyses on high-performing firms similar to Stam et al. (2014). 
Focusing on prosperous firms is another limitation of this study. While it might be difficult to get failing firms to speak at length about their failures, case studies on this would shed more light on the characteristics of failing SMEs. A comparative analysis between high performing and failing SMEs would further validate our findings since it is not prudent to extrapolate from the findings of prosperous firms to determine the characteristics of failing ones.

Further, researchers who are working on consolidating the literature into a general theory of SME growth and performance need to assess the role that the external environment plays in determining SME prosperity. This study did not cover the external environmental factors given that the framework employed is heavily based on the internal dynamics of the firm. Despite the difficulties that these firms face in their external environment; which is not always enabling, our findings show that with strategic foresight and a cadre of forward thinking and strategic leadership, firms are able to achieve prosperity.

This study has several implications for managers as well as policy makers. Owner/managers of SMEs in the Caribbean need to focus on how to develop skills and capabilities that relate to strategic leadership. As our findings demonstrate, strategic leadership is one of the key characteristics of entrepreneurs archiving growth and prosperity for their firms. Entrepreneurs can improve their strategic thinking and foresight by enrolling into training programmers and have an international exposure as a first step to start cultivating how to strengthen their business performance. Moreover, since networking is found to be a strong characteristic of prosperous small firms in the Caribbean, policymakers might want to consider promoting industry clusters that can 
help in the strengthening of networks. These clusters can help entrepreneurs share their experiences and learn from others in order to improve the performance of their firms. 


\section{Acknowledgement}

The research reported on in this study stems from a larger research project on how well small businesses in the Caribbean compete with multinational enterprises in highly competitive markets. Some of the findings from that study have been published in Williams (2015b).

\section{References}

Acevedo, S., Cebotari, A., and T. Turner-Jones. 2013. "Caribbean small states: Challenges of high debt and low growth.” IMF Occasional Paper. Accessed 15 August 2016. https://www.imf.org/external/np/pp/eng/2013/022013b.pdf

Altman, E. I., and P. Narayanan. 1997. "An international survey of business failure classification models.” Financial Markets, Institutions \& Instruments 6 (2): 1-57.

Amit, R., and P.J.H. Schoemaker. 1993. "Strategic assets and organizational rent." Strategic Management Journal 14(1): 33-46.

Barbero, J.L., Casillas, J.C. and H.D. Feldman. 2011. "Managerial capabilities and paths to growth as determinants of high-growth small and medium-sized enterprises.” International Small Business Journal 29(6): 671-694.

Barkham, R., Gudgin, G. and E. Hanvey. 2002. "Determinants of small firm growth: An inter-regional study in the United Kingdom 1986-90.” London: Jessica Kingsley.

Barney, J. 1991. "Firm resources and sustained competitive advantage." Journal of Management 17(1): 99-120.

Barringer, B.R., Jones, F.F. and D.O. Neubaum. 2005. "A quantitative content analysis of the characteristics of rapid-growth firms and their founders.” Journal of Business Venturing 20(5): 663-687.

Baum, J.R., Locke, E.A. and K.G. Smith. 2001. "A multidimensional model of venture growth.” Academy of Management Journal 44(2): 292-303.

Blackburn, R., Brush, C. and A. Blank. 2009. "Understanding the challenges to growth in entrepreneurial firms: cases from the UK and USA.” In Paper to the XXIII RENT conference, 19-20, Budapest.

Blackburn, R.A., Hart, M. and T. Wainwright. 2013. "Small business performance: business, strategy and owner-manager characteristics.” Journal of Small Business and Enterprise Development 20(1): 8-27.

Blair-Henry, P. B., and C. Miller. 2008. "Institutions vs. policies: A tale of two islands." National Bureau of Economic Research, No. w14604, 1-16.

Campbell, N.D., Heriot, K.C., Jauregui, A. and D.T. Mitchell. 2012. "Which state policies lead to US firm exits? Analysis with the economic freedom index.” Journal of Small Business Management 50(1): 87-104.

Carr, D. 1986. "Narrative and the real world: An argument for continuity." History and Theory. 25(2): 117-131.

Davidsson, P., Kirchhoff, B., and J-A. Hatemi. 2002. "Empirical analysis of business growth factors using Swedish data." Journal of Small Business Management 40(4): 332-349.

Davidsson, P., Achtenhagen, L. and L. Naldi. 2006. "What do we know about small firm growth?” In: The life cycle of entrepreneurial ventures 361-398. US: Springer. 
Delmar, F. and J. Wiklund. 2008. “The effect of small business managers' growth motivation on firm growth: A longitudinal study.” Entrepreneurship Theory and Practice 32(3): 437-457.

Dobbs, M. and R.T. Hamilton. 2007. "Small business growth: recent evidence and new directions.” International Journal of Entrepreneurial Behavior \& Research 13(5): 296-322.

Eisenhardt, K.M. and M.E. Graebner. 2007. “Theory building from cases: Opportunities and challenges.” Academy of Management Journal 50(1): 25-32.

Eisenhardt, K.M. 1989. "Building theories from case study research." Academy of Management Review 14(4): 532-550.

Elliott, J. 2005. "Using narrative in social research: Qualitative and quantitative approaches.” Sage.

Escribá-Esteve, A., Sánchez-Peinado, L. and E. Sánchez-Peinado. 2008, "Moderating influences on the firm's strategic orientation-performance relationship.” International Small Business Journal 26(4): 463-489.

Fletcher, M. and S. Harris. 2002. "Seven aspects of strategy formation: Exploring the value of planning.” International Small Business Journal 20(3): 297-314.

Freel, M.S., and P.J.A. Robson. 2004. "Small firm innovation, growth and performance: Evidence from Scotland and Northern England.” International Small Business Journal 22(6): 561-575.

Gibb, A., and L. Davies. 1990. "In pursuit of frameworks for the development of growth models of the small business.” International Small Business Journal 9(1): $15-31$.

Gibb, A.A. 2000. "SME policy, academic research and the growth of ignorance, mythical concepts, myths, assumptions, rituals and confusions.” International Small Business Journal 18(3): 13-35.

Goffee, R., and R. Scase. 1995. "Corporate realities: The dynamics of large and small organisations.” Routledge.

Hall, G. 1995. "Surviving and prospering in the small firm sector." Thomson Learning Emea.

Hamilton, R.T. 2012. "How firms grow and the influence of size and age." International Small Business Journal 30 (6): 611-621.

Hannan, M. T. 1997. "Inertia, density and the structure of organizational populations: Entries in European automobile industries, 1886-1981.” Organization Studies 18(2): 193-228.

Hannan, M. T., and J. Freeman. 1988. "The ecology of organizational mortality: American labor unions, 1836-1985.” American Journal of Sociology 94(1): 25-52.

Hansen, B., and R.T. Hamilton. 2011. "Factors distinguishing small firm growers and non-growers.” International Small Business Journal 29(3): 278-294.

Harris, D.J. 1997. “Jamaica's Export Economy: Towards a Strategy of Export-led Growth.” (No. 5). Ian Randle Publishers.

Hart, M. and G. Gudgin. 1999. "Small-firm growth and public policy in Northern Ireland: making the difference?” Environment and Planning C: Government and Policy 17(5): 511-525.

Hart, M. and S. Roper. 2004. "Small firm growth and public policy in the UK: what exactly are the connections?” In: EISB Conference, 8-10, Turku, Finland.

Huggins, R. (2000). "The success and failure of policy-implanted interfirm network initiatives: Motivations, processes and structure.” Entrepreneurship and Regional Development 12(2): 211-236. 
Jovanovic, B. 1982. "Selection and the evolution of industry." Econometrica 50(3): 649-670.

Kirkwood, J. 2009. “To grow or not? Growing small service firms.” Journal of Small Business and Enterprise Development 16(3): 485-503.

Kiss, A.N., Danis. W.M., and S.T. Cavusgil. 2011. "International entrepreneurship research in emerging economies; a critical review and research agenda.” Journal of Business Venturing 27 (2): 266-290.

Kristiansen, S. 2014. "Social networks and business success." American Journal of Economics and Sociology 63(5): 1149-1171.

Lashley, J. 2003. "Small and micro business issues in Barbados: Investigating the contingent environment." Paper presented at SALISES fourth annual conference, 124, Sherbourne Centre, Barbados, 15- $17^{\text {th }}$ January.

Leitch, C., Hill, F., and H. Neergaard. 2010. "Entrepreneurial and business growth and the quest for a “comprehensive theory”: Tilting at windmills?” Entrepreneurship Theory and Practice 34(2): 249-260.

Littunen, H., and H. Niittykangas. 2010. "The rapid growth of young firms during various stages of entrepreneurship.” Journal of Small Business and Enterprise Development 17(1): 8-31.

Lyles, M.A., Baird, I.S., Orris, B., and D.F. Kuratko. 1993. "Formalized planning in small business: increasing strategic choices.” Journal of Small Business Management 31(2): 38-50.

Mazzarol, T., Reboud, S., and G.N. Soutar. 2009. "Strategic planning in growth oriented small firms." International Journal of Entrepreneurial Behavior \& Research 15(4): 320-345.

McKelvie, A., and J. Wiklund. 2010. "Advancing firm growth research: A focus on growth mode instead of growth rate." Entrepreneurship Theory and Practice 34(2): 261-288.

Minto-Coy, I. D. Forthcoming. "From the Periphery to the Centre: Start-up and Growth Strategies for Minority Diaspora Entrepreneurs” International Journal of Entrepreneurship and Small Business.

Nicholson, L. A., and J.G. Lashley. 2016. "Understanding the Caribbean enterprise: Insights from MSME and family-owned businesses.” London: Palgrave MacMillan.

Obeng, B. A., Robson, P., and H. Haugh. 2014. "Strategic entrepreneurship and small firm growth in Ghana.” International Small Business Journal 32(5): 501-524.

Penrose, E. 1959. The theory of the growth of the firm.” New York: John Wiley.

Rangone, A. 1999. "A resource-based approach to strategy analysis in small-medium sized enterprises. Small Business Economics 12(3): 233-248.

Reijonen, H., Laukkanen, T., Komppula, R., and S. Tuominen. 2012. “Are growing SMEs more market-oriented and brand-oriented?” Journal of Small Business Management 50(4): 699-716.

Richbell, S.M., Watts, H.D., and P. Wardle. 2006. “Owner-managers and business planning in the small firm.” International Small Business Journal 24(5): 496-514.

Sadler-Smith, E., Hampson, Y., Chaston, I., and B. Badger. 2003. "Managerial behavior, entrepreneurial style, and small firm performance.” Journal of Small Business Management 41(1): 47-67.

Schwab, K. and X. Sala-i-Martin. 2015. "World Economic Forum’s Global Competitiveness Report, 2014-2015.” Switzerland: World Economic Forum. Accessed 15 August 2016. http://reports.weforum.org/global-competitivenessreport-2014-2015/ 
Smallbone, D., Leig, R., and D. North. 1995. "The characteristics and strategies of high growth SMEs.” International Journal of Entrepreneurial Behavior \& Research 1(3): 44-62.

Smallbone, D., and P. Wyer. 2000. "Growth and Development in the small business.” In: Enterprise and Small Business: Principles, Practice and Policy Carter, S., Jones-Evans, D., 100-130, England: Pearson Education Limited.

Stam, W., Arzlanian, S., and T. Elfring. 2014. "Social capital of entrepreneurs and small firm performance: A meta-analysis of contextual and methodological moderators." Journal of Business Venturing 29(1): 152-173.

Steffens, P., Davidsson, P., and J. Fitzsimmons. 2009. "Performance configurations over time: Implications for growth-and profit-oriented strategies.” Entrepreneurship Theory and Practice 33(1): 125-148.

St-Jean, E., Julien, P.A. and J. Audet. 2008. "Factors associated with growth changes in" gazelles".” Journal of Enterprising Culture 16(02): 161-188.

Storey, D.J. 2011. "Optimism and chance: the elephants in the entrepreneurship room." International Small Business Journal 29(4): 303-21.

Storey, D.J. 1994. "Understanding the small business sector.” University of Illinois at Urbana-Champaign's Academy for Entrepreneurial Leadership, Historical Research Reference in Entrepreneurship.

Thornhill, S., and R. Amit. 2003. "Learning about failure: Bankruptcy, firm age and the resource-based view.” Organization Science 14(5): 497-509.

Watson, J. 2007. "Modeling the relationship between networking and firm performance." Journal of Business Venturing, 22(6), pp.852-874.

Wernerfelt, B. 1984. "A resource-based view of the firm." Strategic Management Journal 5(2): 171-180.

Wiklund, J., Patzelt, H. and Shepherd, D.A., 2009. "Building an integrative model of small business growth.” Small Business Economics 32(4): 351-374.

Williams, D.A. 2015a. "Resources and business failure in SMEs: Does size matter?” Journal of Business and Management 20(2): 89-103.

Williams, D.A. 2015b. "Competing against multinationals in emerging markets: Case Studies of SMEs in the Manufacturing sector." UK: Palgrave Macmillan.

Wint, A.G. 2003. "Competitiveness in small developing economies: Insights from the Caribbean." University of West Indies Press.

World Bank. 2016. "Doing business report: Measuring regulatory quality and efficiency." Washington DC. Accessed 15 August 2016. http://www.doingbusiness.org/reports/global-reports/doing-business-2016

Yin, R.K. 2013. “Case study research: Design and methods.” Sage Publications. 